\title{
水中超音波の定在波を用いた非接触マイクロマニピュレーション*
}

\author{
小塚晃透*1, 辻 内亭*2 \\ 三留秀 人 $^{* 1}$, 福 田 敏 男*3
}

\section{Noncontact Micro Manipulation Using an Ultrasonic Standing Wave Field in Water}

Teruyuki KOZUKA, Toru TUZIUTI, Hideto MITOME and Toshio FUKUDA

\begin{abstract}
Manipulation of micro objects has been studied experimentally using radiation force of ultrasound. Alumina particles $16 \mu \mathrm{m}$ in diameter and suspended in water were trapped and agglomerated at every half wavelength in a standing wave field of $1.75 \mathrm{MHz}$. Slight changes in frequency brought about a lateral shift in the column of agglomerated particles. An L-shaped standing wave field agglomerated the particles at intersection points of grids which were the nodes of the sound pressure. Using orthogonal standing wave fields, the agglomerated particle changed its shape depending on the relative force ratio. Since the acoustic radiation force differs depending on the size, shape, density and compressibility of the particle, selective manipulation is possible. Alumina particles and nylon particles are separated by agglomerating them at nodes and antinodes, respectively. By applying focused traveling ultrasound on the trapped particles, only limited clusters of particles were transported, which demonstrated spatially selective manipulation.
\end{abstract}

Key Words : Ultrasound, Acoustic Radiation Pressure, Micro Machine, Noncontact Manipulation, Standing Wave Field

\section{1. 緒言}

マイクロマシンの研究開発において, 微小領域で微 小物体に力を作用させる技術が求められている(1). 微 小領域では, 固体の摩擦, 液体の粘性等, 通常のスケ ールでは無視できた現象が大きく作用するため, 従来 の機構をその構造のまま小形化したのでは不都合を生 じる(2).また，微細なほこりが大きな障害物として作 用するため, 微小領域ではクリーンな非接触マニピュ レーションが必要である(3).このような需要に応える ものとして、レ一ザ光の放射圧 ${ }^{(4)(5)}$ や静電気(6)(7) を用 いた研究開発が数多く行われている、レーザ光を用い る場合、ナノメートルオーダの微小物体を操作するこ とが可能となるが, 媒質の透明度や対象物の光の屈折 率などに関する制約がある，静電力を用いる場合は比 較的強い力が得られるが, 電極における電気分解の問 題があるなど, 各手法には一長一短があり状況に応じ て使い分けることが必要である.

* 原稿受付 1996 年 7 月 18 日.

*1 正員, 通商産業省工業技術院名古屋工業技術研究所( 462 名古屋市北区平手町 1 ).

*2 通商産業省门:業技術院名古屋工: 業技術研究所.

*3 正員, 名古屋大学大学院L学研究科( 46401 名古虚市下 種区不老町 1)
超音波を用いて微小物体に力を作用することも可能 である(8) (12). 流体媒質中を伝搬する超音波を物体で 遮ると物体を音の進行方向に押す力が現れる.この力 は音響放射圧と呼ばれ, 非接触で物体に力を作用させ ることが可能である(13).この力は微弱であるが, 音響 レンズや山面形振動子を用いることにより, 容易に波 長のオーダまで集束させることができる，したがっ て, 高周波の超音波を用いれば, 特定の微小領域に音 の放射压による力の作用範囲を限定することができ る.また, 振動子と平行に反射板を設置して定在波音 場を生成することにより, 音波の波長に比べて十分に 小さい微小球を音压の節もしくは腹に捕捉することも 可能である(14). さらに, 上述の静電力ゃレーザ光の放 射圧による力では困難な, 電気的にシールドされた場 や不透明体に対しても, 超音波は伝搬する媒質さえあ れば離れたところから音場を制御して, 力を作用する ことが可能である.

これまで超音波の力学的応用は, 粉体工学の分野に 扔いて溶液中での粒子の凝集・分散等(15)(16) を確率的 に操作するものが多かった。これは, 音響放射圧によ る力の大きさが非常に小さいため，工学的に忘用する 場合, 対象物が軽量の物あるいは無重力空間に揖いて の利用等に限定されるためである(17). しかしながら， 
微小物体を対象とするマイクロマシンのアクチュエー 夕としては十分であると著者らは考え, 超音波を用い たマイクロマニピュレーションに関する基礎研究をこ れまで行ってきた(18) (20). 本報では, 水中に眯濁した アルミナ微粒子”を超音波の定在波で凝集・捕捉し，音 場を変化することにより凝集形状を操作すること、押 よびそれらに集束超音波を照射し, 特定の位置の凝集 粒子のみを選択的に輸送することを試みる。また、マ イクロマシンはバイオテクノロジーにおける練胞操作 等(21)へ0)忍用が期待されている0)で, 生体細胞を定 在波音場中に投人した際の捕捉についても示す.

\section{2. 超音波の力学的作用}

\section{$2 \cdot 1$ 放射圧による力超音波が流体媒質中を伝} 搬すると，音のエネルギーの流れが生じる。この中に 物体を置くと, 物体を超音波の伝搬方向に押寸力が現 れる。これは音の放射压による力で，物体を音場中に 䠐くことによって, 音波の反射, 吸収, 屈折, 回折が起 こり, 物体の回りの音のエネルギー密度場に不均一が できることに起因している(図1)。音のエネルギー密 度 $E$ の音場㠶置かれた半径 $a$ の球に作用する音の 放射庈による力 $F$ は。

$$
F=\pi a^{2} E Y_{p}
$$

で与えられる(13).ここで放射力関数 $Y_{p}$ は球の材質と $k a(k=2 \pi / \lambda, \lambda$ は媒質中の波衰 $)$ に依存する複雑な関数 である，k(が 1 より十分大きく，かつ球による音の 回折, 透過, 球の弾性振動や音源との間の定在波など の影響がすべて無視できる理想的な場合には，Ypは 1 に近づく.Nyborg(2) によれば, 球径が波長に比べ て十分に小さい場合 $(k a \ll 1)$, 剛球に作用する放射压 による力は次式で与えられる。

$$
F=V\left[B \nabla\left\langle K_{a}\right\rangle-\nabla\left\langle P_{a}\right\rangle\right]+D
$$

ここで $V\left(=(4 / 3) \pi a^{3}\right)$ は小球の体積, $\left\langle K_{a}\right\rangle,\left\langle P_{a}\right\rangle$ はそ れぞれ小球に作用する音の連動工ネルギーとポテンシ ヤルエネルギーの時間㣿均值， $\nabla$ はこう配を表す演算 子ナブラである。また，媒筫拀よび小球の密度をそれ

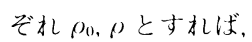

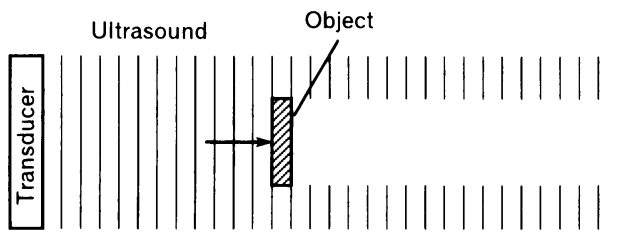

Fig. 1 A simplified model of acoustic radiation pressure of ultrasound acting on a surface of the object

$$
B=3\left(\rho-\rho_{0}\right) /\left(2 \rho+\rho_{0}\right)
$$

である。 $D$ は $k a$ や密度の比を含む複雑な形で与えら れるが,この項は $\left\langle K_{a}\right\rangle$ や $\left\langle P_{a}\right\rangle$ が本質的に均一分布 をしているときにのみ重要で, 定在波音場中では無視 することができる(22).さらに, 小球の圧縮性まで考慮 する場合は，媒質および小球の圧縮率をそれぞれ $\beta_{0}$, $\beta$ とすれば, それらの比 $\gamma\left(=\beta / \beta_{0}\right)$ を用いることにより,

$$
F=V\left[B \nabla\left\langle K_{a}\right\rangle-(1-\gamma) \nabla\left\langle P_{a}\right\rangle\right]
$$

となる(22)(23). 特に, 音圧振幅 $A$, 角周波数 $\omega$ の正弦 波平面音波同士が音速 $c_{0}$ の媒質中で干涉して生じる 1 次元の定在波音場を考えると, 音压 $p$ は,

$$
p=2 A \cos k x \sin (\omega t+\psi)
$$

と表される. $\psi$ は入射波と反射波の初期位相差であ る.このとき式 $(4)$ は,

$$
F=V[B+(1-\gamma)] k \frac{A^{2}}{\rho_{0} c_{0}^{2}} \sin 2 k x
$$

となり, 放射圧による力は半波長の周期で変化するこ とがわかる. 竹内らはこの式に基づき， $B+(1-\gamma)>$ 0 の場合には，球は定在波の音圧分布の節に捕捉され， 一方 $B+(1-\gamma)<0$ の場合には, 音圧分布の腹に捕捉 されることを示した(14). 流体中に固体粒子が懸濁し ている多くの場合, $\rho>\rho_{0}, \beta<\beta_{0}$ であるので, $B+(1$ $-\gamma)>0$ となり, 粒子は図 2 に示すように半波長間隔 で生じる音圧分布の節に捕捉されることになる。

$2 \cdot 2$ 放射力の集束 放射圧による力(放射力)は, 音場によって決まるため, 音場を制御することによっ て, 力の作用範囲も制御することが可能である.

超音波は山面形振動子や音響レンズを用いることに より, 容易に集束させることができる。図 3 に示すよ うな開口半径 $a$, 曲率半径 $l_{f}$ の凹面球形振動子の場 合, 曲率の中心(焦点)付近に音の強さの強い狭い領域 が発生する．焦点面で音波ビームの軸に垂直な断面を 考えると音王分布は同心円状に分布するが，音圧が最 初に 0 となる同心円(first nodal circle)の直径 $l_{d}$ は,

$$
l_{d}=1.2 \lambda l_{f} / a
$$

で与えられ、この川内を全音響出力の $84 \%$ が通過する

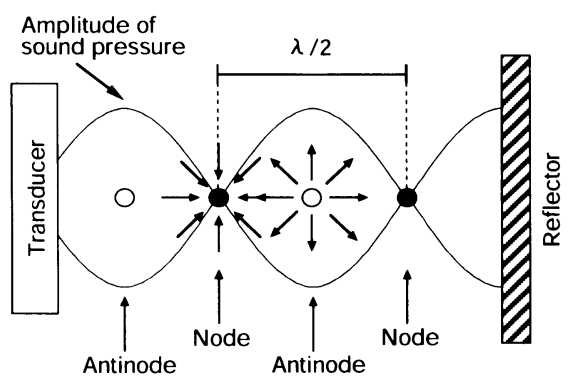

Fig. 2 Radiation pressure in a standing wave field 
ことが知られている(24).すなわち，焦点距離が振動子 の半径のオーダであれば，ほとんどの音のエネルギー は波長のオーダの限られた領域を通ることになる。ま た，焦点付近の音軸方向における音圧ピーク值の-6 $\mathrm{dB}$ で定義される focal zone $l_{z}$ は,

$$
l_{z}=4 l_{f}^{2} /\left(2 l_{n}+l_{f}\right)
$$

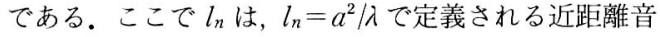
場の領域である。したがって音の放射圧の作用範囲も 特定のポイントに限定することが可能である.今回の 実験で用いた凹面形振動子 $\left(5.6 \mathrm{MHz}, \lambda=0.27 \mathrm{~mm}, l_{f}\right.$ $=40 \mathrm{~mm}, a=10 \mathrm{~mm})$ の場合, $l_{d}=1.3 \mathrm{~mm}, l_{z}=8.2$ $\mathrm{mm}$ となる。

図 4 は, 水中に抢けるこの山面形振動子の音場をシ

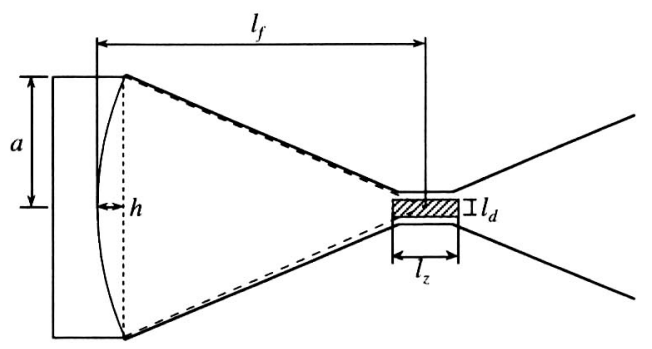

Fig. 3 Geometry of a focused sound field generated by a concave spherical transducer

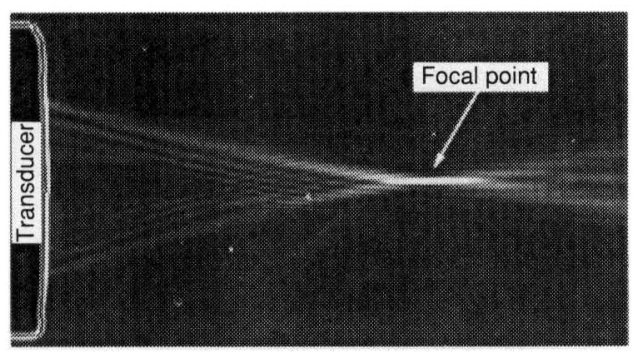

Fig. 4 Schlieren image of a focused sound field generated by a concave spherical transducer

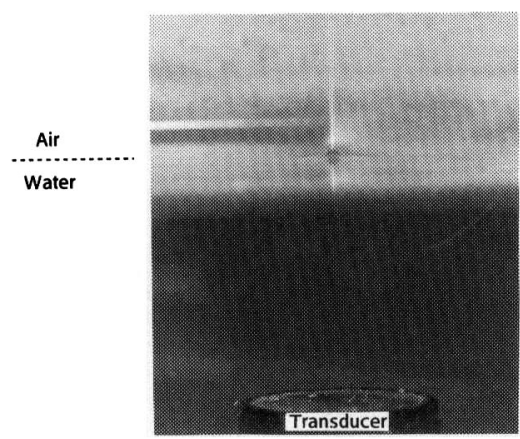

Fig. 5 Ultrasonic fountain using focused ultrasound
ユリーレン法により可視化したものである.これか ら，超音波が焦点付近で集束するようすがわかる．図 5 は，この振動子を水面に向け，焦点位置を水面に一 致させた際の噴水現象を示す(25). 音場の集束に対応 して放射圧による力も集束され，ごく限られた狭い領 域のみの水面が押し上げられた結果，振動子の寸法に 比べてはるかに細い噴水が生じることがわかる。ま た,この振動子は後述する $3 \cdot 4$ 節において, 焦点位置 のアルミナ粒子に大きな力を作用させる実験にも用い る。このように集束超音波を用いることにより，振動 子全体としての出力は小さいままで, 特定の狭い領域 のみに選択的に放射圧による大きな力を作用させるこ とができる。

\section{3. 実験}

$3 \cdot 1$ 定在波による微粒子の捕捉 実験の第一段 階として, 水中において超音波の定在波を用いたアル ミナ粒子の捕捉を試みた。図 6 に実験装置の構成を示 す。ここで用いた振動子は 2 章の山面形とは異なり, 平面形の振動子である．直径 $20 \mathrm{~mm}$ の円形平板圧電 セラミックス(共振周波数 $1.75 \mathrm{MHz}$ )を, シリコンゴ ムのバッフル (直径 $30 \mathrm{~mm}$ )で周りを固め, 水中に上 向きに固定した，振動子の周波数特性を調べるため に，反射板を設置しない状態で $1.75 \mathrm{MHz}$ のトーンバ ースト波をパワーアンプにより増幅し，約 $20 \mathrm{~V}_{\mathrm{pp}}$ の 電圧で振動子を駆動して進行波音場を形成した。振動 子中心軸上の距離 $l=20,40,60 \mathrm{~mm}$ における受波音 圧を測定した結果の周波数特性を図 7 に示す。音圧が 最大となる周波数带域は比較的広く, $1.7 \sim 1.9 \mathrm{MHz}$ において約 $10^{5} \mathrm{~Pa}$ の音压が発生していることがわか る.この振動子上方 $30 \mathrm{~mm}$ の位置にセラミックスの 反射板を水平に設置した。振動子を $1.75 \mathrm{MHz}, 20$ $V_{\mathrm{pp}}$ の連続正弦波で駆動し，反射板との間に定在波音 場を形成した(波長 $0.86 \mathrm{~mm}$ ). 平均径 $16 \mu \mathrm{m}$ のアル ミナ粒子の奬濁液を定在波音場中にピペットで注入

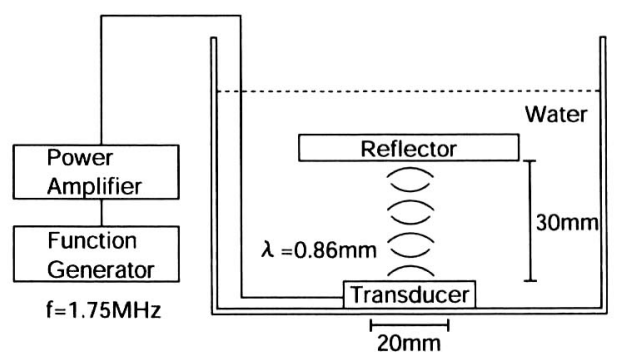

Fig. 6 Experimental apparatus for trapping of particles in an ultrasonic standing wave field 


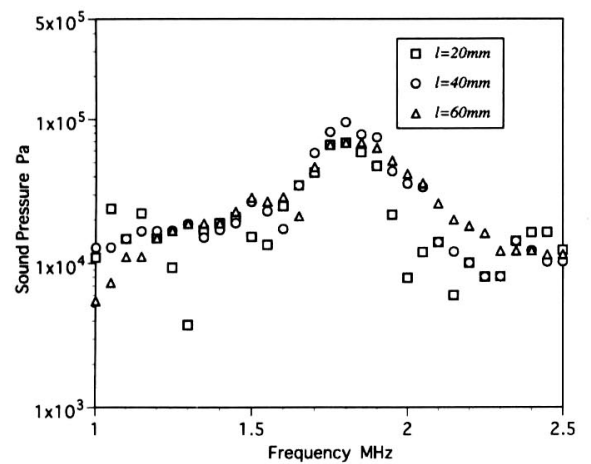

Fig. 7 Frequency characteristics of the plain-type transducer

し, 粒子の挙動を CCD カメラを用いて観察した.

図 8 に, 音圧の節に捕捉され凝集したアルミナ粒子 を示す. 振動子と反射板の間に約 70 箇所の音圧の節 が存在し, そのほとんどに粒子が捕捉されていること がわかる. 振動子と反射板の距離をわずかに変化させ ると, 粒子に作用する力の大きさが半波長間隔で周期 的に変化することが実験時の観察で見られたが，いず れの場合も粒子を捕捉することが可能であった．粒子 は振動子の中心軸上のみならず, その周辺の複数の点 においても捕捉されていることがわかる. 図 9 は, シ ュリーレン法を用いてこの音場を光学的に可視化した 映像である．定在波音場は振動子前面の広い範囲に生 成され, 粒子を捕捉する力学的な作用範囲は, 広く分 布していることがわかる。図 10 は,アルミナ懸濁液 を横からビーム軸に垂直に注入した際の写真である. 懸濁液は, 半波長間隔の層に凝集しながら流れている が, 眯濁液の注入を止めると, やがて粒子は図 8 に示 すように, 振動子中心軸付近の複数の安定点に捕捉さ れる. 音場中で粒子に作用する力は 4 章にて詳しく考 察するが, 周波数 $1.75 \mathrm{MHz}$ の定在波音場中で $16 \mu \mathrm{m}$ のアルミナ粒子が受ける力は, $V=2.145 \times 10^{-15} \mathrm{~m}^{3}, B$ $=0.994, \gamma=0.0051, k=7.331 \times 10^{3} \mathrm{~m}^{-1}, \rho_{0}=1000$ $\mathrm{kg} / \mathrm{m}^{3}, c_{0}=1500 \mathrm{~m} / \mathrm{s}, A=1.013 \times 10^{5} \mathrm{~Pa}$ ( 1 気圧) とす ると, 式(6)より最大 $142 \mathrm{pN}$ と考えられる.この力 の作用範囲は図 9 に示すように広範囲に分布している が, 振動子の中心軸付近において捕捉する力の極大值 が複数存在すると考えられる.

$3 \cdot 2$ 微粒子捕捉位置の変化 定在波の音圧の節 にアルミナ粒子を捕捉している状態で周波数をわずか に変化させると粒子の移動が観察された。図 11 に周 波数を $1.745 \mathrm{MHz}$ から $1.746 \mathrm{MHz}$ に変化させた際 の凝集粒子の挙動を示す. 全体が右に移動し, 前後に

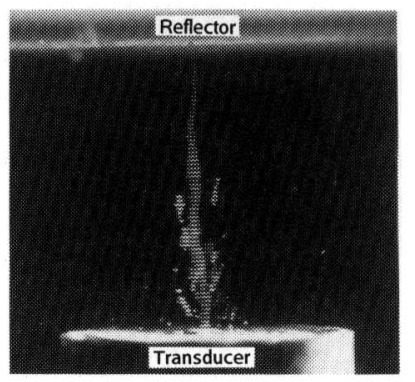

Fig. 8 Alumina particles trapped in an ultrasonic standing wave field

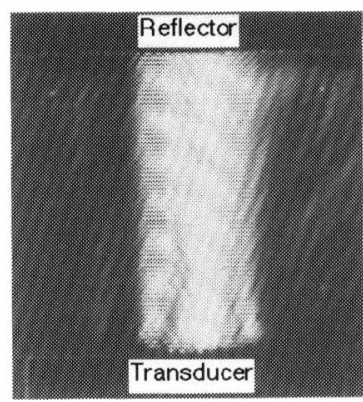

Fig. 9 Schlieren image of the ultrasonic standing wave field generated by the plain-type transducer

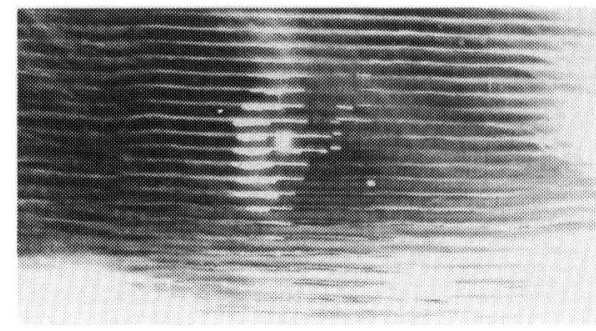

Fig. 10 Motion of alumina suspension in an ultrasonic standing wave field

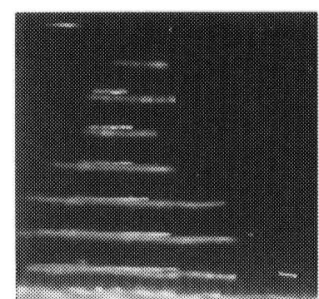

(a) $1.745 \mathrm{MHz}$

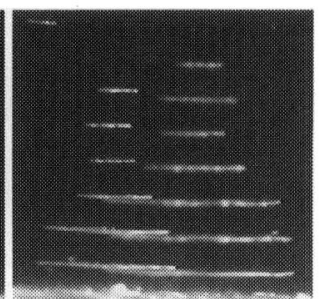

(b) $1.746 \mathrm{MHz}$
Fig. 11 Shift of trapped particles when the frequency has changed 
重なっていた粒子群の分離が確認される．周波数を変 え, 波長が変化したことで音場が変化し，そのため力 学的な安定点の分布が変化したためと考えられる. 捕 捉された粒子は, 新たな周波数における近傍の新たな 安定点に移動する. 同様の現象は振動子と反射板の距 離を変化させた際にも観察された。振動子と反射板の 相対位置が変化することによって音場が変化し，粒子 は移動したと考えられる。

共振周波数付近で周波数の変化量が小さい場合は粒 子の移動が見られるが, 周波数を大きく変化させ共振 周波数から大きく離れると粒子を捕捉する力は哀え， 粒子は周波数の変化とともに徐々に落下した. 本実験 では共振周波数を中心に約 $10 \%$ の周波数増減まで粒 子の捕捉が可能であった. この範囲は振動子の周波数 特性および印加電圧により異なり，音響放射圧による 力が重力等の他の力を上回る場合に, 粒子の捕捉が可 能となると考えられる. 振動子と反射板の距離 $L$ は, 今回の実験で試みた数十 $\mathrm{mm}$ の範囲ではいずれの位 置においても粒子の捕捉が可能であった。周波数 $f$ または距離 $L$ を連続的に変化すると, どちらを変化 した場合も粒子を捕捉する力の強さが周期的に変化し た.シュリーレン法によりそのときの媒質の密度変化 を観察すると, $f$ または $L$ の変化に伴い振動子と反射 板の間の距離に存在する音波の周期が半周期增減する

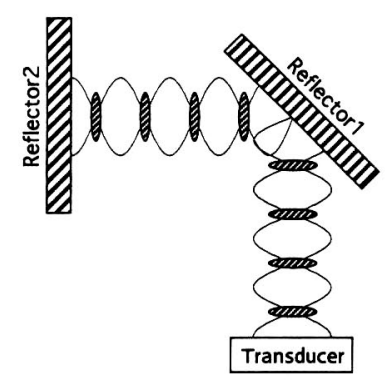

Fig. 12 Schematic diagram of an L-shaped standing wave field

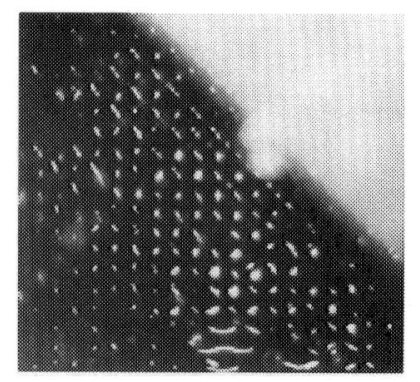

Fig. 13 Particles trapped in the L-shaped standing wave field
ごとに, 媒質の密度変化が観察された. 振動子と反射 板の間隔が半波長の整数倍となる場合に系全体が共鳴 し, 粒子を捕捉する力は極大となると考えられる.

$3 \cdot 3$ 直交定在波音場中の微粒子の凝集超音波 は反射板を用いて容易にその伝搬方向を変えることが できるので, 反射板を組合せることで複雑な音場が形 成できると考えられる，図 12 に示すように，振動子 上方の反射板 1 を音軸に対して $45^{\circ}$ の角度に設置し, 振動子から放射された超音波を水平方向に反射する. そして, 反射した超音波の音軸と垂直にもう一枚の反 射板 2 を設置すると, 反射板 1 において $90^{\circ}$ の角度で 反射する逆 L 字型の定在波が形成される.この音場 中にアルミナ懸濁液を注入したところ, 振動子および 反射板 2 近傍ではこれまでと同様に音軸に垂直な方向 に半波長間隔で粒子は整列したが, 反射板 1 近傍は図 13 に示すように凝集した。 入射波と反射波のそれぞ れの定在波の音圧の節が直角に交差し, 粒子はその交 点に捕捉されていることがわかる.

これまでは単一の振動子による均一な音場を扱って きたが, 複数の独立した音場を組合せることで, 微粒 子の凝集状態を操作することができると考えられる. 三浦は縞モード矩形振動板超音波音源を用いて, 振動 面に平行な方向に音圧の節が格子状の二次元分布をも つ定在波を生成し,この音場中で微小球は音圧の節線 の交点ではなく, 音圧の節線の中心に向かう力が働く ことを示している(26). 本報では 2 組の振動子と反射 板を用いて形成される定在波音場を直角に交差し，そ れぞれ独立して駆動することで, 交点における二次元 音場の制御を試みた。この音場中では，各定在波によ る音響放射圧の合力が作用し，各定在波の音圧の節の 交点に粒子は凝集すると考えられる．音場中にアルミ ナ粒子を投入し，粒子の挙動を観察した。

図 14 に実験の概略を示す. 粒子はそれぞれの定在 波音場のビーム軸に沿って捕捉される. それぞれの振

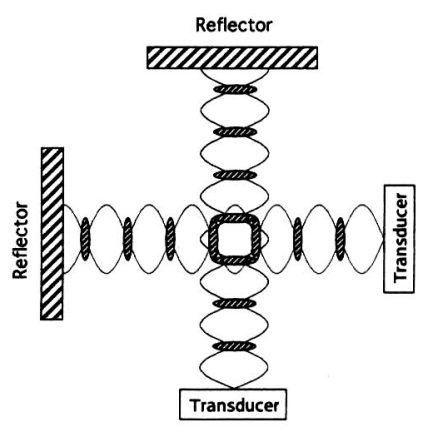

Fig. 14 Orthogonal standing wave fields 


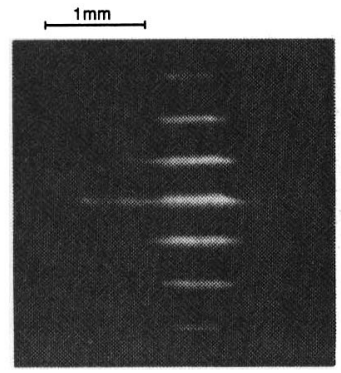

(a) Vertical $>$ Horizontal

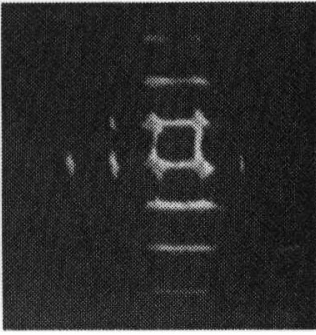

(b) Vertical $=$ Horizontal

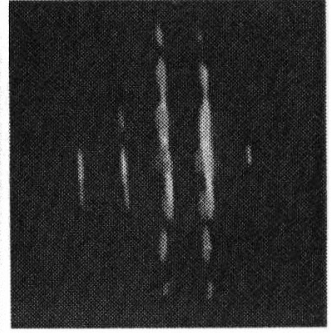

(c) Vertical< Horizontal

Fig. 15 Changes in the shape of agglomeration of particles depending on the ratio of vertical and horizontal force

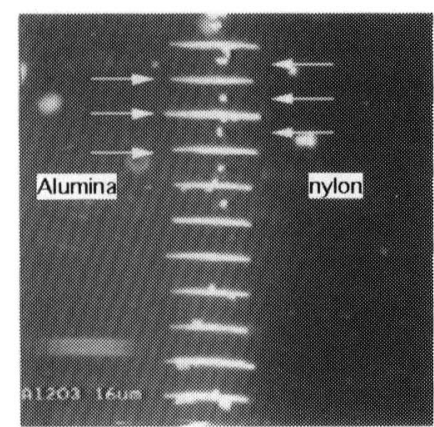

Fig. 16 Nylon particles trapped at antinodes of sound pressure

動子に加える電圧の比率を変えることで交点付近での 粒子の凝集形状が変形する。図 15 に実験結果を示す. 図 15(a) は垂直方向の力が支配的な場合である.水 平方向の振動子に加わる電压を増加すれば, 粒子は 徐々に水平方向の定在波の音圧の腹から節に向かう力 を受けて移動し，音圧の節の交点を中心とした菱形に 変形する。両方の力がそれぞれ同等であるならば，凝 集形状は図 15（b）に示すように格子を形成する。水 平方向の振動子に加わる電圧をさらに増加し, 水平方 向の力が支配的になれば，凝集形状は図 15(c)のよう に変形する。

\section{$3 \cdot 4$ 混在粒子の分離・移動 粒子に作用する力} は，式（６）に示すように同一の音場中であっても粒子 の大きさ，材質等により異なる．図 16 は，定在波の音 圧の節に平均径 $16 \mu \mathrm{m}$ のアルミナ粒子を捕捉してい る中に, 平均径 $80 \mu \mathrm{m}$ のナイロン粒子を投入したとこ ろ, 音压の腹にナイロン粒子が捕捉されたことを示し ている。表 1 に水, アルミナ, ナイロン, 空気の物性 值より求めた $B+(1-\gamma)$ の值を示寸.ナイロンの密 度と音速はアルミナより水に近いため, 作用する力は アルミナより小さい.また表面積が大きいため気泡の
Table 1 Physical properties of water, alumina, nylon and air

\begin{tabular}{|l|r|r|r|r|r|}
\hline & $\begin{array}{r}\text { Density } \\
{\left[\mathrm{kg} / \mathrm{m}^{3}\right]}\end{array}$ & $\begin{array}{r}\text { Sound } \\
\text { speed } \\
{[\mathrm{m} / \mathrm{sec}]}\end{array}$ & \multicolumn{1}{c|}{$B$} & $\gamma$ & $\mathrm{B}+(1-\gamma)$ \\
\hline Water & 1000 & 1500 & 0.0 & 1.0 & 0.0 \\
\hline Alumina & 3950 & 10544 & 0.994 & 0.0051 & 1.989 \\
\hline Nylon & 1110 & 2620 & 0.102 & 0.295 & 0.807 \\
\hline Air & 1.29 & 331 & -2.988 & 15842 & -15844 \\
\hline
\end{tabular}

付着している可能性が高い. 気泡は水に比べ密度が小 さく圧縮率が大きいので, 前述の式( 6 )において $B$ $+(1-\gamma)<0$ となり, 音压の腹に向かう力を受ける. ナイロンに付着している気泡の体積 $V$ は非常に小さ いが, $B+(1-\gamma)$ の絶対值が十分に大きいため,わず かな気泡によりナイロン粒子には音圧の腹に向かう力 が作用すると考えられる.このように密度, 圧縮率, 音速, 体積により作用する力が異なるので, これらの 特性の異なる混在粒子を超音波により分離することが 可能である。

分離した粒子を取出すには，任意の粒子のみに力を 作用して移動することが必要である，定在波音場と対 照的に, 進行波は一方向性の音響放射圧による力を発 生する. 2 ・2 節に示したように超音波は凹面形振動子 を用いることにより簡単に集束させることができ, 音 響放射圧による力もまた集束し, この力は波長のオー ダの微小領域に作用する。

定在波音場中で捕捉された粒子に, 集束音波による 集束放射力を作用させる実験を行った(図 17，18)，3・ 1 節の定在波で捕捉した凝集粒子のコラム(垂直方向) に集束形振動子(直径 $20 \mathrm{~mm}$ の凹面形圧電セラミッ クス, 共振周波数 $5.6 \mathrm{MHz}$, 焦点距離 $40 \mathrm{~mm}$ ) の焦点 位置を合せて水平方向から超音波を放射したところ, 焦点付近の極めて限られた領域の粒子が捕捉されてい る位置から高速ではじき飛ばされた。この実験の場 


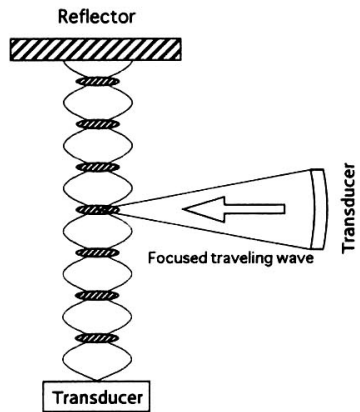

Fig. 17 Focusing of acoustic radiation pressure on specific particles

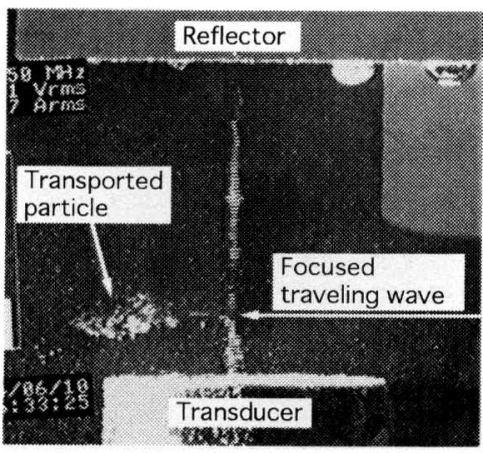

Fig. 18 Transportation of trapped particles applying focused radiation pressure of traveling ultrasound

合, 式 ( 7 )で与えられる first nodal circle は $1.3 \mathrm{~mm}$ であるから定在波により半波長 $0.43 \mathrm{~mm}$ 間隔で凝集 した微粒子のコラムのうちの特定の部分のみが捕捉位 置から搬送されることになる．この值は周波数を高く することでさらに小さくでき，任意の凝集粒子のみを はじきとばして回収することが可能である.

振動子に集束形を用いると，焦点位置に非常に強力 な力を集中する一方, それ以外では力は作用しないた め, 特定の微小物体のみに大きな力を作用させるには 適切な方法であると考えられる。

$3 \cdot 5$ 細胞の捕捉 マイクロマニピュレーション 技術はバイオテクノロジーにおける細胞融合のための 細胞操作や, 遺伝子工学における DNA 操作等への応 用が考えられる(7)(21). Wu は, 対向する集束超音波を 用いてラテックス微粒子扔よび蛙の卵をマニピュレー トできることを示している(12)，定在波音場による細 胞操作を試みた. タバコの根の細胞(直径約 $50 \mu \mathrm{m}$, 長さ約 $1 \mathrm{~mm})$ を $3 ・ 1$ 節で示した定在波音場中 $(1.75$ $\left.\mathrm{MHz}, 10^{5} \mathrm{~Pa}\right)$ に投入し, 音圧の節に捕捉することを 試みた。図 19 はその結果である。半波長間隔で層状

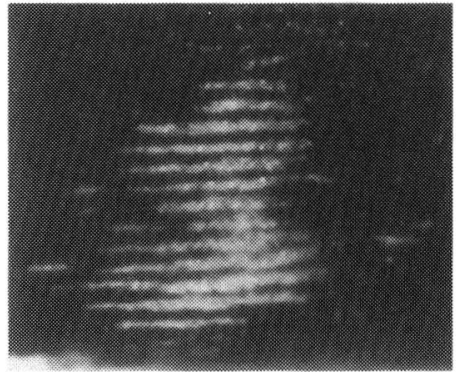

Fig. 19 Biological cell trapped in a standing wave field

に凝集していることがわかる，しかしながら，同一条 件のアルミナ微粒子の場合に比べて作用する力は微弱 であった。本手法は式 ( 6 )に示すように密度と圧縮率 の $\rho, \beta$ が異なる際に超音波の音響放射圧が作用する が, 細胞の主成分は水であり媒質に近いため, 式(6) で表される音響放射圧による力は微弱であると考えら れる。

\section{4. 考 察}

超音波の音響放射圧を力として利用するためには， その大きさが問題となる。水中に眯濁した直径 $16 \mu \mathrm{m}$ の球形アルミナ粒子(比重 3.95 , 質量 $8.47 \times 10^{-12} \mathrm{~kg}$ ) には, 重力 $83.0 \mathrm{pN}$, 浮力 $21.0 \mathrm{pN}$, 差引き $62.0 \mathrm{pN}$ の力が重力の方向に作用する。本実験で用いた 1.75 $\mathrm{MHz}$ の定在波音場中の音圧振幅を 1 気压 $\left(1.013 \times 10^{5}\right.$ $\mathrm{Pa})$ とすると, 直径 $16 \mu \mathrm{m}$ の球形アルミナ粒子には, 式 ( 6 ) より最大 $142.6 \mathrm{pN}$ の力が音圧の腹から節に向 かって作用することになる。この力は，音圧および物 体の音響特性, 大きさ等によって異なるが, 数十 $\mu \mathrm{m}$ のマイクロマシンのアクチュエータとして十分に活用 できると考えられる。また，音場中で粒子は凝集する ため, 凝集によって体積 $V$ が大きくなるとともに粒 子に作用する力は大きくなる，実際には円盤状に凝集 するが球形の場合で考えると, 直径 $64 \mu \mathrm{m}$ の球形アル ミナ粒子には, 重力 $5313 \mathrm{pN}$, 浮力 $1345 \mathrm{pN}$, 差引き $3968 \mathrm{pN}$ の下方に向かう力と，音響放射圧による音压 の節に向かう力 $9127 \mathrm{pN}$ が作用する.

このように同じ音場中に置かれても，小球の形状や 物理的な特性によって受ける力が異なるため,この性 質を用いることにより液体中の懸濁微粒子の分離技術 や大きさによる分級技術に応用することができると考 えられる。これに関連した研究として, 山越らは, 微 小粒子が受ける放射圧による力と粘性力による抵抗が 粒径によって異なることを利用し, 移動定在波中での 微小粒子の粒径の違いによる追従性の差から, 粒径計 
測を行う方法を提案している(27). 安田らは液体中で の微粒子を定在波を用いて濃縮，回収することを試み ているが, 濃縮効果が微粒子の粒径により異なり, 小 さな粒径になるほど濃縮が困難になることを示してい $ろ^{(28)}$.

これらの実験から，超音波を用いることにより，微 粒子の寸法・形状・材質の差異による選択的マニピュ レーションが実現可能と考えられる。ささらに, 本実験 で示したように, 集束超音波による放射圧を用いれば, 空間的にも微粒子を選択的にマニピュレートすること が可能となる.

\section{5. 結 論}

本報では, 水中超音波を用いて微粒子の非接触マイ クロマニピュレーションを試みた．水中において懸濁 したアルミナ微粒子は, 定在波音場中で半波長間隔に 存在する音圧の節に捕捉されて凝集し，音軸方向にコ ラムを形成した，粒子を捕捉する力は音のビーム軸付 近が最も強いが, その力は振動子前面の広い範囲にわ たって作用し，周波数等を変化させて音場が変化する と，粒子は水平面内を移動することがわかった．音波 は反射板を用いて容易にその進行方向を変えることが できるので，2枚の反射板を組合せて L 字形の定在波 音場を作ると，直角に反射する反射板近傍において粒 子の捕捉位㯰を格子状の定点に固定できた．さらに 2 組の振動子と反射板を用いて直交する定在波音場を生 成し，それぞれの振動子への印加電圧の比を変えるこ とにより, 両軸の交点付近に捕捉された微粒子の凝集 形状を変形させることができた。

アルミナ微粒子が音圧の節に捕捉されている定在波 音場中に, 気泡が付着していると考えられるナイロン 粒子を投入すると, ナイロン粒子は音王の腹に捕捉さ れ，音響的に特性の異なる物質を超音波で分離できる ことを示した，分離した凝集粒子のコラムは，直角方 向から凝集間隔と同程度に集束させた超音波の進行波 を照射することにより, 特定の部分の凝集粒子のみを 搬送できる。超音波による力は細胞にも作用するの で，超音波の音響放射压:を用いたマニピュレーション 技術はバイオテクノロジーへの応用も可能である.

最近, 振動板にたわみ振動を氻振させることで空中 に超音波を放射させ，その放射圧により数 $\mathrm{kg} の$ 質量 の物体を浮揚させる研究が行われている(29)(30).これ は，本報での原理とは異なるものであるが，重量物の 超音波マニピュレーションの可能性を示している。な お，すべて0物を超音波で動かす必要はなく，今村ら は静電力およびレーザ光を組合せた細胞操作を試みて
いるが(21), このように他の力と複合化して，それぞれ の特徵を生かした使い方をすることにより, 実用的な マイクロマニピュレーションが可能となる.

\section{文献}

(1) 江刺正喜, 機論, 62-594, C(1995), 417-422.

（2）福田敏男・光岡豊一, 夢のマイクロロポット, (1995), 7085 , オーム社.

（3） Jin, J.・樋口俊郎, 電気学会論文誌, 116-E (1996), 28-33.

(4) Ashkin, A., Phys. Rev. Lett., 24-4 (1970), 156-159.

（5）杉浦忠男 - 河田聡 - 南茂夫, 分光研究, 39-6(1990)，342 346 .

（6）渡辺恒雄, 静電気学会誌, 16-6 (1992)，483-492.

(7) Morishima, K., Fukuda, T., Arai, F., Ishihara, H., Matsuura, H. and Yoshikawa, K., 6th Int. Sympo. Micro Machine \& Human Science Proc., (1995), 145152.

(8) Takeuchi, M., Abe, H. and Yamanouchi, K., Jpn. J. Appl. Phys., 35-5B (1996), 3244-3247.

(9) Whitworth, G. and Coakley, W. T., J. Acoust. Soc. Am., 91-1 (1992), 79-85.

(10) Whitworth, G. and Nyborg, W. L., J. Acoust. Soc. Am., 90-4 (1991), 2091-2096.

(11) Tolt, T. L. and Feke, D. L., J. Acoust. Soc. Am., 91-6 (1992), 3152-3156

(12) Wu, J., J. Acoust. Soc. Am., 89-5 (1991), 2140-2143.

（13）根岸勝雄 - 高木堅志郎, 超音波技術, (1984)，59-69，東京 大学出版会.

（14）竹内正男, 日本音響学会誌, 52-3, (1996), 203-209.

(15) Schetter, B. and Funcke, J. (小室弥栄 - 中島耀二訳), 粉 砕, 38(1994), 21-29.

（16）奥平有三 - 安藤秀行 - 佐藤宗武 - 宮南啓, 粉体工学会誌, 32-5(1995), 311-318.

（17）羽田野甫 - 金井義和 - 池上雄二 ・藤井積 - 斉藤勝利, 日 本音響学会誌, 47-1 (1991), 40-47.

(18) Mitome, H., Kozuka, T. and Tuziuti, T., 4th Int. Sympo. Micro Machine \& Human Science Proc., (1993), 68-74.

(19) Kozuka, T., Tuziuti, T., Mitome, H. and Fukuda, T., 5th Int. Sympo. Micro Machine \& Human Science Proc., (1994), 83-87.

(20) Kozuka, T., Tuziuti, T., Mitome, H. and Fukuda, T., 6th Int. Sympo. Micro Machine \& Human Science Proc., (1995), 179-185.

（21）今村誠・細井功一・水野彰, 静電気学会誌, 13-5(1989), $417-424$.

(22) Nyborg, W. L., J. Acoust. Soc. Am., 42-5(1967), 947 952.

(23) Gor'kov, L. P., Sou. Phys. - Doklady, 6-9 (1962), 773-775.

（24）実吉純一・菊池喜充・熊本乙彦, 超音波技術便覽(新訂 版), (1978), 166-174, 日刊工業新聞社.

（25）辻内亨 - 小塚晃透 - 留秀人, 日本音響学会平成 6 年度 春季研究発表会講演論文集-2, (1994), 1011-1012.

（26）三浦光，日本音響学会誌，47-12 (1991)，941-947.

（27）山越芳樹 - 小林汭樹，日本音響学会誌，50 3(1994)，198204.

(28) Yasuda, K., Kiyama, M. and Umemura, S., J. Acoust. Soc. Am., 99-2 (1996), 1248-1251.

(29) Hashimoto, Y., Koike, Y. and Ueha, S., J. Acoust. Soc. Jpn. (E), 16-3 (1995), 189-192.

（30）橋場邦夫・寺尾㶳 -久納孝彦、機論, 61-590, C (1995), $3931-3936$ 